\author{
라이코펜 급여와 포장방법이 재래돼지 등심육의 저장 중 품질 \\ 특성에 미치는 영향 \\ 김동훈* • 임동균* • 성필남* • 하경희* · 조수현* · 김진형* • 이종문* · 김영태* · 김일석** . 진상근** \\ 농촌진흥청 축산과학원*, 진주산업 대학교 동물소재공학과**
}

\title{
Effects of Dietary Lycopene Supplementation and Packaging on Quality Traits in Longissimus Muscle of Korean Native Pigs during Storage
}

Dong Hun Kim*, Dong Gyun Lim*, Pil Nam Seong*, Kyoung Hee Hah*, Soo Hyun Cho*, Jin Hyoung Kim*, Jong Moon Lee*, Young Tae Kim*, Il Suk Kim** and Sang Keun Jin**

National Institute of Animal Science, RDA*,

Department of Animal Resources Technology, Jinju National University**

\begin{abstract}
The objective of this study was to evaluate the effect of dietary lycopene supplementation on meat quality in Longissimus Muscle of Korean native pigs. Meat samples were obtained from pigs which had been fed with finishing pig diets containing basal diets (C), $200 \mathrm{ppm}$ lycopene (T1), $400 \mathrm{ppm}$ lycopene (T2), and $800 \mathrm{ppm}$ lycopene (T3). Longissimus muslce $\mathrm{pH}$ was not influenced by feeding lycopene. Total microbial counts of treatments were significantly lower than those of control at 0 day of storage $(\mathrm{p}<0.05)$. Counts of lactic acid bacteria and coliform of T2 and T3 were significantly lower than those of control and $\mathrm{T} 1$ at 0 day of storage $(\mathrm{p}<0.05)$. Regardless of packaging, microbial counts increased as the storage period increased $(\mathrm{p}<0.05)$. While water-holding capacity (WHC) values of the treatments were lower than those of control, cooking losses values of treatments were higher than those of control $(p<0.05)$. Therefore, it can be concluded that Korean native pigs fed lycopene supplemented diets affect the microbial counts and meat quality (volatile basic nitrogen, WHC and cooking loss) compared with conventional ones. These results may show a fundamental data on production of Korean native pork.
\end{abstract}

(Key words : Lycopene, Korean native pigs, Quality)

\section{I. 서 론}

소비자의 소득 수준 향상과 더불어 국민 식 생활의 서구화 경향으로 인하여 동물성 지방의 섭취가 늘면서 고혈압, 뇌혈관질환과 같은 각 종성인병의 주범이 식육에 있다는 점이 각종 매스컴 등에 보도되면서 육류 소비에 대한 부
정적 견해가 제기되고 있다. 따라서 인체에 유 익한 식육 생산의 중요성이 강조되고 있다. 현 재 우리나라에서 소비량이 가장 많은 돼지고기 는 국민건강에 커다란 영향을 주는 주요 육류 식품으로 인식되고 있으며, 특히 돼지는 여러 가축중에서 사료에너지로부터 체지방 에너지로 의 전환율이 가장 높은 것으로 알려져 있다

Corresponding author : Dong Gyun Lim, National Institute of Animal Science, Suwon, 441-706, Korea. Tel : 82-31-290-1684, Fax : 82-31-290-1697, E-mail : elpollo9@snu.ac.kr 
(Seo와 Park, 1998; Jin 등, 2003).

재래돼지는 오랫동안 우리나라 기후와 풍토 에도 잘 견딜 수 있는 적응력이 매우 강한 특 성을 갖고 있으나(Kwon 등, 2001), 대부분의 재래종은 일반적으로 개량종에 비하여 체구가 적고 만숙종이며 오랫동안 버크셔종과의 교배 로 외모색이 한가지로 고정되지 못한 단점을 가지고 있다. 그럼에도 불구하고 우리나라 재 래돼지고기가 다른 품종에 비해 고기 조직이 쫄깃쫄깃하고 지방은 단단하고 백색이며, 육색 이 선홍색이며, 부드럽고 향미가 좋은 것으로 알려져 있다(Jin 등, 2001; Choi, 2004). 이와 같 이 개량종과의 차별화를 위하여 재래돼지에 대 한 관심이 날로 증가되고 있고 소비자 또한 재 래돼지고기에 대한 선호도가 증대되면서 농가 의 고소득 산업으로 관심을 끌고 있다 (Cho 등, 2007).

토마토에 가장 많이 함유되어 있는 carotenoid 계통의 일종인 라이코펜은 손상된 세포를 보호 하는 강력한 항산화제이다(DiMascio 등, 1989; Rao와 Agarwal, 1999; Agarwal과 Rao, 1998). 최 근에 암, 동맥경화, 당뇨병 등의 질병을 일으키 거나 노화촉진 원인물질 가운데 한가지로 알려 진 활성산소에 대하여 그 소거활성을 천연의 항산화제 및 carotenoids을 대상으로 검정하였는 데, lycopene이 a-tocophenol에 비해 약 100배, $\beta$ -carotene에 비해서는 약 2배 더 강하게 나타났 다고 보고되고 있다 (Mascio 등, 1989). 또한, lycopene이 HL-60 세포(전골수성 백혈병 세포) 의 성장억제 그리고 자궁암, 유방암, 폐암세포 의 성장억제 작용 등이 있음이 보고되고 있다
(Rao와 Agarwal, 1999). 그리고 전립선암 (Giovannucci 등, 1995; Kucuk, 2002; Pastori 등, 1998)과 소화기 계통암(Franceschi 등, 1994)의 예방과 치료에 매우 효과적인 것으로 알려져 있으며, 종양발병 위험 (Sharoni 등, 1997)을 낮 추는 것으로 보고되고 있다. 최근 국내에서 사 료내 다양한 첨가제를 급여한 돼지고기생산을 위한 많은 연구가 이루어져 왔지만, 라이코펜 급여에 따른 재래 돼지고기에 대한 연구는 아 직까지 이루어지지 않고 있는 실정이다.

따라서 본 연구에서는 라이코펜 급여에 따른 재래돼지 등심육의 저장 중 품질특성의 차이를 구명하여 재래 돈육을 생산하기 위한 기초 자 료를 제시하고자 수행하였다.

\section{ㅍ. 재료 및 방법}

\section{1. 공시가축 및 실험설계}

\section{(1) 공시가축}

공시가축은 일령 $(120 \pm 1$ 일 $)$ 이 비슷하고 개시 체중이 $75 \pm 1 \mathrm{~kg}$ 되는 재래돼지 (Berkshire) 240 두를 공시하여 Table 1 과 같이 4 개의 처리구에 3 반복으로 각 돈방당 20 두씩 배치하고, 시험을 42 일간 급여하여 종료체중이 $108 \pm 2 \mathrm{~kg}$ 에 도달 한 공시가축을 출하하여 시험을 종료하였다.

(2) 공시사료

공시사료는 부경양돈농협 사료공장에서 생산 된 일반 배합사료(basal diet, C)를 기초로 하여 Table 1 과 같이 합성 정제 라이코펜 (synthetic

Table 1. Experimental design

\begin{tabular}{|c|c|c|c|c|}
\hline \multirow{2}{*}{ Items } & \multicolumn{4}{|c|}{ Treatments $^{1)}$} \\
\hline & $\mathrm{C}$ & $\mathrm{T} 1$ & $\mathrm{~T} 2$ & $\mathrm{~T} 3$ \\
\hline No. of plots & 3 & 3 & 3 & 3 \\
\hline No. of pigs / group & 20 & 20 & 20 & 20 \\
\hline Total pigs & \multicolumn{4}{|c|}{240} \\
\hline Feeding period (day) & \multicolumn{4}{|c|}{42} \\
\hline
\end{tabular}

1) C: basal diet (no-addition), T1: basal diet + add synthetic lycopene, 200 ppm, T2: basal diet + add synthetic lycopene, 400 ppm, T3: basal diet + add synthetic lycopene, 800 ppm. 
lycopene)을 첨가수준별로 혼합하였다. 생체중 $75 \pm 1 \mathrm{~kg}$ 까지는 육성기 사료를 출하 시까지는 비육기 사료를 무제한 급여하였으며, 그 원료 구성 및 화학적 조성은 Table 2와 같다.

(3) 사양관리

시험구의 돈방 면적, 사료 및 급수 시설은 동일하게 부여하였고, 돈사는 자유롭게 개폐할 수 있는 개방형 골함석 지붕이며, 급수는 자유 급수를 하였고, 기타 사양관리는 일반적인 관 행법에 준하여 실시하였다.

\section{2. 조사항목}

\section{(1) $\mathrm{pH}$}

$\mathrm{pH}$ 는 $10 \mathrm{~g}$ 의 시료와 증류수 $100 \mathrm{ml}$ 을 homogenizing하여 pH meter (IQ 150, Lab. Science, Carlsbad, CA, USA)를 사용하여 3반복을 수행 하였다.

(2) 미생물분석

총균수와 젖산균측정은 시료 $10 \mathrm{~g}$ 과 $90 \mathrm{~mL}$ 의 멸균 Peptone 수(Difco Laboratories, Detroit, MI, USA)에 넣고 stomacher (Interscience BagMixer ${ }^{\circledR}$, St Nom La Breteche, France)에서 2분간 균질시 킨 다음 10 배 희석법으로 희석하였다. 희석한 시료 $1 \mathrm{~mL}$ 을 총균수는 plate counter agar (Difco Lab., USA)와 젖산균수는 MRS agar (Difco Lab., $\mathrm{USA})$ 에 혼합하여 평판으로 조제한 후, $37^{\circ} \mathrm{C}$ 에 서 48시간 배양한 다음 나타난 colony 수를 colony counter (IPI Inc., Microcount 1008, Los Angeles, CA, USA)를 이용하여 계수하였다. 미 생물 수는 시료 $1 \mathrm{~g}$ 당 colony forming unit (CFU)로 나타내었다. 대장균군(coliform)수의 경 우 coliform petrifilm(3M Health care, USA; AOAC. 2000)을 이용하여 희석액을 $1 \mathrm{ml}$ 씩 접 종한 후 $35^{\circ} \mathrm{C}$ 에서 24 시간 배양한 다음 군락 수 를 계수하였다.

\section{(3) 가열감량}

신선육 시료를 $2 \mathrm{~cm}$ 두께로 일정하게 절단하 여 무게를 측정하고 $80^{\circ} \mathrm{C}$ 항온수조에서 시료내
Table 2. Chemical composition (\%) of the experiment diets ${ }^{3)}$

\begin{tabular}{lcc}
\hline Ingredients & Grower & Finisher \\
\hline \hline Corn & 53.00 & 33.50 \\
Wheat & 9.50 & 30.00 \\
Soybean meal & 26.00 & 12.50 \\
Wheat bran & - & 4.00 \\
Rice bran & - & 1.00 \\
Rapeseed meal & - & 3.00 \\
Palm kernel meal & - & 2.00 \\
Cotton seed meal & - & 3.00 \\
Limestone & 1.24 & 1.45 \\
Tri calcium phas. & 0.82 & 0.60 \\
Animal fat & 5.10 & 4.20 \\
Molasses & 3.50 & 4.00 \\
Salt & 0.30 & 0.30 \\
L-lysine HCl & 0.20 & 0.20 \\
DL-mathionine & 0.04 & - \\
Vitamin primix ${ }^{1)}$ & 0.10 & 0.10 \\
Mineral primix & 0.10 & 0.10 \\
Phytase & 0.10 & 0.05 \\
Total & 100.00 & 100.00 \\
\hline Chemical composition (\%) & & \\
ME (kcal/kg) & 3,350 & 3,220 \\
Crude protein & 17.50 & 15.50 \\
Lysine & 1.05 & 0.87 \\
Calcium & 0.90 & 0.9220 \\
Total phosphous & 0.50 & 0.50 \\
\hline
\end{tabular}

1) Supplied per kg diets : vitamin A, 4,000 IU; vitamin D, 3,800 IU; vitamin E, $1,500 \mathrm{IU}$; vitamin $\mathrm{K}, 320$ $\mathrm{mg}$; vitamin $\mathrm{B}_{12}, 16 \mathrm{mg}$; thiamin, $8 \mathrm{mg}$; riboflavin, $2 \mathrm{mg}$; pantothenicacid, $11 \mathrm{mg}$; niacin, $20 \mathrm{mg}$; biotin, $0.02 \mathrm{mg}$.

${ }^{2)}$ Supplied per kg diet : Cu, $30 \mathrm{mg}$; Fe, $175 \mathrm{mg}$; Zn, 100 mg; Mn, 90 mg; I, 0.3 mg; Co, 0.5 mg; Se, 0.2 mg.

${ }^{3)} \mathrm{C}$ : basal diet (no-addition), T1: basal diet + add synthetic lycopene, 200 ppm, T2: basal diet + add synthetic lycopene, 400 ppm, T3: basal diet + add synthetic lycopene, $800 \mathrm{ppm}$.

부중심온도가 $70^{\circ} \mathrm{C}$ 가 될 때까지 가열한 다음 꺼내서 냉각시켜 감량된 무게를 백분율(\%)로 산출하였다. 


\section{(4) 전단력}

전단력은 고기시료 $(4 \mathrm{~cm} \times 3 \mathrm{~cm} \times 2.5 \mathrm{~cm})$ 를 80 ${ }^{\circ} \mathrm{C}$ 항온수조에서 시료 내부중심온도가 $70^{\circ} \mathrm{C}$ 가 될 때까지 가열한 다음 꺼내서 냉각시켜 가열 한 시료를 직경 $0.5 \mathrm{inch}^{2}$ 의 core로 시료를 근섬 유 방향으로 채취한 후 Load cell $(50 \mathrm{~kg})$, Crosshead speed $(200 \mathrm{~mm} / \mathrm{min})$ 의 조건으로 전단력 측 정기 (Instron Universal Testing Machine, Model $4465, \mathrm{UK})$ 를 이용하여 측정하였다. 전단력가는 core 시료 각각을 전단하는데 필요한 최대힘의 평균값을 의미한다.

\section{(5) 보수력}

보수력 측정은 Laakkonen 등(1970)의 방법에 따라 미세한 구멍이 있는 $2 \mathrm{ml}$ 튜브의 무게를 칭량하고, 지방과 근막(힘줄)을 제거한 시료를 정확히 $0.5 \mathrm{~g}$ 을 칭량하여 튜브에 넣고 시료와 튜브 무게를 칭량한 다음 $80^{\circ} \mathrm{C}$ 의 Water bath에 서 20 분간 가열한 후 10 분간 실온에서 방냉하 였다. $4{ }^{\circ} \mathrm{C}$ 에서 $2,000 \mathrm{rpm}, 10$ 분 동안 원심분리 한 후 무게를 측정하였으며 다음 공식에 의해 보수력을 구하였다.

$$
\text { 보수력 }=\frac{\text { 수분(\%)-유리수분 }}{\text { 수분(\%) }} \times 100
$$

(6) Volatile basic nitrogen (VBN)

高坂(1975)의 방법을 이용하여 세절육 $10 \mathrm{~g}$ 에 증류수 $90 \mathrm{ml}$ 을 가하여 $14,000 \mathrm{rpm}$ 으로 5 분간 균질한 후 균질액을 whatman No. 1.으로 여과하 여 여과액 $1 \mathrm{ml}$ 을 conway unit 외실에 넣고 내실 에는 $0.01 \mathrm{~N}$ 붕산용액 $1 \mathrm{ml}$ 와 지시약 $(0.066 \%$ methyl red $+0.066 \%$ bromocresol green)을 3방울 가한다. 뚜껑과의 접착부위에 glycerine을 바르고 뚜껑을 닫은 후 $50 \% \mathrm{~K}_{2} \mathrm{CO}_{3} 1 \mathrm{ml}$ 을 외실에 주입 후 즉시 밀폐시킨 다음 용기를 수평으로 교반한 후 $37^{\circ} \mathrm{C}$ 에서 120 분간 배양시켰다. 배양 후 0.02 $\mathrm{N} \mathrm{H}_{2} \mathrm{SO}_{4}$ 로 내실의 붕산용액을 측정하였다.

\section{3. 통계처리}

시험결과는 SAS program(SAS, 2003)을 이용 하여 분산분석 및 Duncan의 다중검정을 실시하 여 처리구간의 유의성 $(\mathrm{p}<0.05)$ 을 검정하였다.

\section{III. 결과 및 고찰}

\section{1. $\mathrm{pH}$ 및 미생물분석}

양돈 사료 내 라이코펜 첨가에 따른 재래돈 육등심의 저장 중 $\mathrm{pH}$ 변화를 Table 3 에 나타내

Table 3. Changes of $\mathrm{pH}$ of porks fed lycopene with different packaging during storage at $4^{\circ} \mathrm{C}$ $(n=3)$

\begin{tabular}{ccccc}
\hline \multirow{2}{*}{ Packaging } & Treatments $^{1}{ }^{1}$ & \multicolumn{3}{c}{ Storage period (days) } \\
\cline { 3 - 5 } & $\mathrm{C}$ & $5.72 \pm 0.09$ & $5.78 \pm 0.14$ & $5.81 \pm 0.13$ \\
\hline \multirow{3}{*}{ Aerobic } & T1 & $5.75 \pm 0.29$ & $5.79 \pm 0.25$ & $5.82 \pm 0.20$ \\
& T2 & $5.75 \pm 0.33$ & $5.72 \pm 0.33$ & $5.77 \pm 0.32$ \\
& T3 & $5.69 \pm 0.16$ & $5.69 \pm 0.16$ & $5.70 \pm 0.12$ \\
\hline \multirow{2}{*}{ Vacuum } & $\mathrm{C}$ & $5.72 \pm 0.09$ & $5.87 \pm 0.23$ & $5.92 \pm 0.18$ \\
& T1 & $5.75 \pm 0.29$ & $5.84 \pm 0.07$ & $5.85 \pm 0.09$ \\
& T2 & $5.75 \pm 0.33$ & $5.61 \pm 0.14$ & $5.66 \pm 0.18$ \\
& T3 & $5.69 \pm 0.16$ & $5.83 \pm 0.18$ & $5.87 \pm 0.22$ \\
\hline
\end{tabular}

${ }^{1)} \mathrm{C}$ was basal diet and $\mathrm{T} 1, \mathrm{~T} 2$, and $\mathrm{T} 3$ was basal diet $+200,400$, and $800 \mathrm{ppm}$ of synthetic lycopene, respectively. 
었다. $\mathrm{pH}$ 의 경우 라이코펜 첨가의 차이를 확인 할 수 없었고 $(\mathrm{p}>0.05)$, 포장방법간의 차이 또한 확인할 수 없었다. 본 연구결과와 유사한 문헌 은 거의 보고된 바 없지만, 관련연구에서 양돈 사료 내 합성 라이코펜을 $20 \mathrm{ppm}$ 까지 첨가시 $\mathrm{pH}$ 가 대조구와 처리구 모두 5.4 정도로 통계적 인 유의차가 나타나지 않았다고 보고하고 있다 (주, 2005).

라이코펜 첨가에 따른 재래돈육등심의 저장 기간 동안의 미생물 수의 변화를 Table 4, 5, 6 에 나타내었다. 저장기간 중 총균수의 경우 (Table 4) 저장 0 일차에서만 대조구(무첨가구)보 다 라이코펜 첨가구에서 미생물수가 더 낮은 값을 나타내었다 $(\mathrm{p}<0.05)$. 저장기간에 따라서 함기포장, 진공포장 모두 총균수가 유의적으로 증가하였다 $(\mathrm{p}<0.05)$. 전반적으로 진공포장구가 함기포장구 보다 총균수가 더 낮은 값을 나타 내었다.

저장기간 중 젖산균의 경우(Table 5) 저장 0 일차의 처리구 $(400,800 \mathrm{ppm})$ 가 무첨가구나 처 리구 $(200 \mathrm{ppm})$ 보다 더 낮은 값을 나타내었고. 저장 9 일차의 함기포장에서도 동일한 결과를 나타내었다 $(\mathrm{p}<0.05)$. 또한, 저장기간에 따라서 포장방법에 상관없이 젖산균수가 유의적으로
증가하였다 $(\mathrm{p}<0.05)$.

저장기간 중 대장균군수의 경우(Table 6) 저 장 0 일차에서만 처리구 $(400,800 \mathrm{ppm})$ 가 무첨가 구나 처리구 $(200 \mathrm{ppm})$ 보다 유의적으로 더 낮은 값을 나타내었고. 저장기간에 따라서 함기포장, 진공포장 모두 대장균군수가 유의적으로 증가 하였다 $(\mathrm{p}<0.05)$. 또한, 진공포장구가 함기포장구 보다 총균수가 더 낮은 값을 나타내었다.

본 연구결과를 통해 저장기간 중 미생물수의 변화에 있어 저장 0 일차에서 사료에 라이코펜 첨가량이 증가함에 따라 총균수와 대장균군수 가 감소하는 것을 확인하였으며, 이는 라이코 펜이 carotenoid 중 가장 강력한 항산화효과를 갖고 있을 뿐 (DiMascio 등, 1989)만 아니라 라 이코펜 급여 재래돼지고기는 일반재래돼지고기 와는 다른 미생물수의 차이를 보인다는 점에서 좀 더 이와 관련한 많은 연구가 필요할 것으로 사료된다.

\section{2. 이화학적인 특성}

양돈 사료내 라이코펜 첨가에 따른 재래돈육 등심의 저장 중 보수력의 변화를 Table 7에 나 타내었다. 전반적으로 함기포장과 진공포장구

Table 4. Changes of total plate counts (log CFU/g) of porks fed lycopene with different packaging during storage at $4^{\circ} \mathrm{C}(\mathrm{n}=3)$

\begin{tabular}{ccccc}
\hline \multirow{2}{*}{ Packaging } & Treatments $^{1)}$ & \multicolumn{3}{c}{ Storage period (days) } \\
\cline { 3 - 5 } & & 0 & 5 & 9 \\
\hline \hline \multirow{2}{*}{ Aerobic } & $\mathrm{C}$ & $3.48 \pm 0.63^{\mathrm{Ca}}$ & $6.42 \pm 0.52^{\mathrm{B}}$ & $9.14 \pm 0.20^{\mathrm{Aa}}$ \\
& $\mathrm{T} 1$ & $2.89 \pm 0.44^{\mathrm{Cb}}$ & $6.33 \pm 0.97^{\mathrm{B}}$ & $8.94 \pm 0.51^{\mathrm{Aab}}$ \\
& $\mathrm{T} 2$ & $2.64 \pm 0.29^{\mathrm{Cbc}}$ & $6.50 \pm 0.80^{\mathrm{B}}$ & $8.65 \pm 0.48^{\mathrm{Ab}}$ \\
& $\mathrm{T} 3$ & $2.26 \pm 0.29^{\mathrm{Cc}}$ & $6.39 \pm 0.56^{\mathrm{B}}$ & $8.79 \pm 0.10^{\mathrm{Aab}}$ \\
\hline \multirow{3}{*}{ Vacuum } & $\mathrm{C}$ & $3.48 \pm 0.63^{\mathrm{Ca}}$ & $5.42 \pm 0.60^{\mathrm{Bb}}$ & $6.84 \pm 0.65^{\mathrm{Ab}}$ \\
& $\mathrm{T} 1$ & $2.89 \pm 0.44^{\mathrm{Cb}}$ & $6.47 \pm 0.14^{\mathrm{Ba}}$ & $7.31 \pm 0.32^{\mathrm{Aab}}$ \\
& $\mathrm{T} 2$ & $2.64 \pm 0.29^{\mathrm{Cbc}}$ & $4.51 \pm 1.06^{\mathrm{Bc}}$ & $7.35 \pm 0.21^{\mathrm{Aab}}$ \\
& $\mathrm{T} 3$ & $2.26 \pm 0.29^{\mathrm{Cc}}$ & $6.65 \pm 0.17^{\mathrm{Ba}}$ & $7.72 \pm 0.46^{\mathrm{Aa}}$ \\
\hline
\end{tabular}

${ }^{1)} \mathrm{C}$ was basal diet and $\mathrm{T} 1, \mathrm{~T} 2$, and $\mathrm{T} 3$ was basal diet $+200,400$, and $800 \mathrm{ppm}$ of synthetic lycopene, respectively.

a,b,c Mean \pm S.D with different superscripts within a column with same packaging differ significantly $(\mathrm{p}<0.05)$.

A,B,C Mean \pm S.D with different superscripts within a row differ significantly $(\mathrm{p}<0.05)$. 
Kim et al. ; Effects of Lycopene Supplementation and Packaging on Quality Traits in Korean Native Pork

Table 5. Changes of lactic acid bacteria (log CFU/g) of porks fed lycopene with different packaging during storage at $4^{\circ} \mathrm{C}(\mathrm{n}=3)$

\begin{tabular}{ccccc}
\hline \multirow{2}{*}{ Packaging } & Treatments $^{1)}$ & \multicolumn{3}{c}{ Storage period (days) } \\
\cline { 3 - 5 } & $\mathrm{C}$ & $2.77 \pm 0.44^{\mathrm{Ca}}$ & 5 & 9 \\
\hline \multirow{3}{*}{ Aerobic } & $\mathrm{T} 1$ & $2.93 \pm 0.80^{\mathrm{Ca}}$ & $5.56 \pm 0.57^{\mathrm{Ba}}$ & $6.35 \pm 0.59^{\mathrm{Ac}}$ \\
& $\mathrm{T} 2$ & $2.20 \pm 0.16^{\mathrm{Cb}}$ & $5.49 \pm 0.65^{\mathrm{Bab}}$ & $8.11 \pm 0.19^{\mathrm{Aa}}$ \\
& $\mathrm{T} 3$ & $0.70 \pm 0.00^{\mathrm{Cc}}$ & $4.80 \pm 0.74^{\mathrm{Bb}}$ & $7.30 \pm 0.90^{\mathrm{Ab}}$ \\
& $\mathrm{C}$ & $2.77 \pm 0.44^{\mathrm{Ca}}$ & $5.36 \pm 0.43^{\mathrm{Bb}}$ & $6.47 \pm 0.31^{\mathrm{Ac}}$ \\
\hline \multirow{3}{*}{ Vacuum } & $\mathrm{T} 1$ & $2.93 \pm 0.80^{\mathrm{Ca}}$ & $6.32 \pm 0.15^{\mathrm{Ba}}$ & $7.97 \pm 0.10^{\mathrm{Aa}}$ \\
& $\mathrm{T} 2$ & $2.20 \pm 0.16^{\mathrm{Cb}}$ & $4.58 \pm 0.27^{\mathrm{Bc}}$ & $7.33 \pm 0.15^{\mathrm{Aab}}$ \\
& $\mathrm{T} 3$ & $0.70 \pm 0.00^{\mathrm{Cc}}$ & $6.35 \pm 0.13^{\mathrm{Ba}}$ & $7.29 \pm 0.74^{\mathrm{Aab}}$ \\
\hline
\end{tabular}

${ }^{1)} \mathrm{C}$ was basal diet and $\mathrm{T} 1, \mathrm{~T} 2$, and $\mathrm{T} 3$ was basal diet $+200,400$, and $800 \mathrm{ppm}$ of synthetic lycopene, respectively.

a,b,c Mean \pm S.D with different superscripts within a column with same packaging differ significantly $(\mathrm{p}<0.05)$.

A,B,C Mean \pm S.D with different superscripts within a row differ significantly $(\mathrm{p}<0.05)$.

Table 6. Changes of coliform (log CFU/g) of porks fed lycopene with different packaging during storage at $4^{\circ} \mathrm{C}(\mathrm{n}=3)$

\begin{tabular}{ccccc}
\hline \multirow{2}{*}{ Packaging } & Treatments $^{1)}$ & \multicolumn{3}{c}{ Storage period (days) } \\
\cline { 3 - 5 } & & 0 & 5 & 9 \\
\hline \multirow{3}{*}{ Aerobic } & $\mathrm{C}$ & $1.51 \pm 0.42^{\mathrm{Ca}}$ & $3.72 \pm 0.27^{\mathrm{B}}$ & $6.83 \pm 0.38^{\mathrm{A}}$ \\
& $\mathrm{T} 1$ & $1.30 \pm 0.27^{\mathrm{Ca}}$ & $3.54 \pm 0.61^{\mathrm{B}}$ & $6.72 \pm 0.16^{\mathrm{A}}$ \\
& $\mathrm{T} 2$ & $0.95 \pm 0.12^{\mathrm{Cb}}$ & $3.93 \pm 0.17^{\mathrm{B}}$ & $6.29 \pm 0.73^{\mathrm{A}}$ \\
& $\mathrm{T} 3$ & $0.75 \pm 0.12^{\mathrm{Cb}}$ & $3.87 \pm 0.23^{\mathrm{B}}$ & $6.56 \pm 0.19^{\mathrm{A}}$ \\
\hline \multirow{3}{*}{ Vacuum } & $\mathrm{C}$ & $1.51 \pm 0.42^{\mathrm{Ca}}$ & $3.33 \pm 0.18^{\mathrm{Bb}}$ & $4.83 \pm 0.91^{\mathrm{Ab}}$ \\
& $\mathrm{T} 1$ & $1.30 \pm 0.27^{\mathrm{Ca}}$ & $3.65 \pm 0.08^{\mathrm{Ba}}$ & $5.73 \pm 0.72^{\mathrm{Aa}}$ \\
& $\mathrm{T} 2$ & $0.95 \pm 0.12^{\mathrm{Cb}}$ & $3.02 \pm 0.27^{\mathrm{Bc}}$ & $3.64 \pm 0.78^{\mathrm{Ac}}$ \\
& $\mathrm{T} 3$ & $0.75 \pm 0.12^{\mathrm{Cb}}$ & $3.55 \pm 0.07^{\mathrm{Ba}}$ & $6.29 \pm 0.38^{\mathrm{Aa}}$ \\
\hline
\end{tabular}

${ }^{1)} \mathrm{C}$ was basal diet and $\mathrm{T} 1, \mathrm{~T} 2$, and $\mathrm{T} 3$ was basal diet $+200,400$, and $800 \mathrm{ppm}$ of synthetic lycopene, respectively.

a,b,c Mean \pm S.D with different superscripts within a column with same packaging differ significantly $(\mathrm{p}<0.05)$.

A,B,C Mean \pm S.D with different superscripts within a row differ significantly $(\mathrm{p}<0.05)$.

모두 대조구보다 처리구에서 저장 중 보수력이 더 낮은 값을 나타내었고 저장 0 일차의 경우 유의적인 차이를 나타내었다 $(\mathrm{p}<0.05)$. 함기포장 구의 경우 $800 \mathrm{ppm}$ 라이코펜 첨가구에서 저장 0 일차보다 저장 9 일차의 보수력이 유의적으로 감소하였다 $(\mathrm{p}<0.05)$. 전단력의 경우 진공포장구 의 $800 \mathrm{ppm}$ 라이코펜 첨가구에서 저장 0 일차
보다 저장 9 일차의 전단력이 유의적으로 감소 하였고 $(\mathrm{p}<0.05)$, 그 이외 경우 처리간의 유의적 인 차이를 나타내지 않았다 (Table 8). Table 9 에서 보는 바와 같이 가열감량의 경우 함기포 장 시료에서 저장 0 일차의 대조구가 처리구보 다 더 낮은 수치를 나타내었고 $(\mathrm{p}<0.05)$, 저장 5 일차와 9 일차에서도 같은 결과를 나타내었지만 
Kim et al. ; Effects of Lycopene Supplementation and Packaging on Quality Traits in Korean Native Pork

Table 7. Changes of $\mathrm{WHC}$ of porks fed lycopene with different packaging during storage at $4^{\circ} \mathrm{C}(\mathrm{n}=3)$

\begin{tabular}{ccccc}
\hline \multirow{2}{*}{ Packaging } & Treatments $^{1)}$ & \multicolumn{3}{c}{ Storage period (days) } \\
\cline { 3 - 5 } & & 0 & 5 & 9 \\
\hline \hline \multirow{3}{*}{ Aerobic } & $\mathrm{C}$ & $61.09 \pm 0.76^{\mathrm{a}}$ & $60.40 \pm 2.15$ & $60.56 \pm 1.27$ \\
& $\mathrm{~T} 1$ & $58.53 \pm 0.45^{\mathrm{b}}$ & $58.98 \pm 3.96$ & $57.35 \pm 3.89$ \\
& $\mathrm{~T} 2$ & $58.59 \pm 2.25^{\mathrm{b}}$ & $57.10 \pm 6.11$ & $59.95 \pm 6.45$ \\
& $\mathrm{~T} 3$ & $58.99 \pm 0.63^{\mathrm{Aab}}$ & $57.31 \pm 0.79^{\mathrm{AB}}$ & $56.22 \pm 1.42^{\mathrm{B}}$ \\
\hline \multirow{3}{*}{ Vacuum } & $\mathrm{C}$ & $61.09 \pm 0.76^{\mathrm{a}}$ & $59.22 \pm 3.96$ & $60.70 \pm 4.15$ \\
& $\mathrm{~T} 1$ & $58.53 \pm 0.45^{\mathrm{b}}$ & $57.09 \pm 2.23$ & $57.60 \pm 0.97$ \\
& $\mathrm{~T} 2$ & $58.59 \pm 2.25^{\mathrm{b}}$ & $57.58 \pm 1.28$ & $54.78 \pm 3.42$ \\
& $\mathrm{~T} 3$ & $58.99 \pm 0.63^{\mathrm{ab}}$ & $57.49 \pm 1.51$ & $58.45 \pm 3.36$ \\
\hline
\end{tabular}

1) C was basal diet and T1, T2, and T3 was basal diet +200 , 400, and 800 ppm of synthetic lycopene, respectively.

${ }^{a, b}$ Mean \pm S.D with different superscripts within a column with same packaging differ significantly $(\mathrm{p}<0.05)$.

A,B Mean \pm S.D with different superscripts within a row differ significantly $(\mathrm{p}<0.05)$.

Table 8. Changes of shear forces values of porks fed lycopene with different packaging during storage at $4^{\circ} \mathrm{C}(\mathrm{n}=3)$

\begin{tabular}{ccccc}
\hline \multirow{2}{*}{ Packaging } & Treatments $^{1)}$ & \multicolumn{3}{c}{ Storage period (days) } \\
\cline { 3 - 5 } & $\mathrm{C}$ & $2.84 \pm 0.65$ & 5 & 9 \\
\hline \hline \multirow{3}{*}{ Aerobic } & $\mathrm{T} 1$ & $2.96 \pm 0.30$ & $2.78 \pm 0.65$ & $2.58 \pm 0.62$ \\
& $\mathrm{~T} 2$ & $2.55 \pm 0.46$ & $2.73 \pm 0.46$ & $2.73 \pm 0.27$ \\
& $\mathrm{~T} 3$ & $3.11 \pm 0.13$ & $2.58 \pm 0.48$ & $2.51 \pm 0.58$ \\
& $\mathrm{C}$ & $2.84 \pm 0.65$ & $3.03 \pm 0.08$ & $2.80 \pm 0.25$ \\
\hline \multirow{3}{*}{ Vacuum } & $\mathrm{T} 1$ & $2.96 \pm 0.30$ & $2.52 \pm 0.54$ & $2.63 \pm 0.08$ \\
& $\mathrm{~T} 2$ & $2.55 \pm 0.46$ & $2.40 \pm 0.42$ & $2.17 \pm 0.78$ \\
& $\mathrm{~T} 3$ & $3.11 \pm 0.13^{\mathrm{A}}$ & $2.85 \pm 0.31$ & $2.62 \pm 0.30$ \\
& & & $2.61 \pm 0.49^{\mathrm{AB}}$ & $2.25 \pm 0.25^{\mathrm{B}}$ \\
\hline
\end{tabular}

${ }^{1)} \mathrm{C}$ was basal diet and $\mathrm{T} 1, \mathrm{~T} 2$, and $\mathrm{T} 3$ was basal diet $+200,400$, and $800 \mathrm{ppm}$ of synthetic lycopene, respectively.

${ }^{A, B}$ Mean \pm S.D with different superscripts within a row differ significantly $(\mathrm{p}<0.05)$.

유의적인 차이는 보여주지 못하였다. 라이코펜 급여에 따른 재래돈육등심의 저장 중 $\mathrm{VBN}$ 의 변화를 Table 10에 나타내었는데 전반적으로 대조구보다 라이코펜 첨가구의 시료가 더 높은 $\mathrm{VBN}$ 값을 나타내었고 $(\mathrm{p}<0.05)$, 함기포장구가 진공포장구보다 약간 높은 $\mathrm{VBN}$ 값을 나타내었
다. VBN 값이 라이코펜 처리구에서 높게 나타 난 것은 라이코펜 처리구가 저장 기간 후에 높 은 총균수를 갖는 것과 관계가 있어 보인다. 본 실험결과와 관련한 선행연구결과에서 양돈 사료 내 합성 라이노펜을 $20 \mathrm{ppm}$ 까지 첨가시 전단력, 보수력, 가열감량에서 모두 대조구와 
Kim et al. ; Effects of Lycopene Supplementation and Packaging on Quality Traits in Korean Native Pork

Table 9. Changes of cooking loss values of porks fed lycopene with different packaging during storage at $4^{\circ} \mathrm{C}(\mathrm{n}=3)$

\begin{tabular}{ccccc}
\hline \multirow{2}{*}{ Packaging } & Treatments $^{1)}$ & \multicolumn{3}{c}{ Storage period (days) } \\
\cline { 3 - 5 } & C & $25.57 \pm 2.59^{\mathrm{ABb}}$ & 5 & 9 \\
\hline \multirow{3}{*}{ Aerobic } & T1 & $28.45 \pm 2.29^{\mathrm{ab}}$ & $23.35 \pm 2.90^{\mathrm{Bc}}$ & $25.25 \pm 2.19^{\mathrm{AB}}$ \\
& T2 & $28.05 \pm 4.30^{\mathrm{ab}}$ & $28.10 \pm 5.71^{\mathrm{ab}}$ & $28.47 \pm 5.82$ \\
& T3 & $32.05 \pm 1.12^{\mathrm{a}}$ & $31.11 \pm 1.41^{\mathrm{a}}$ & $30.42 \pm 1.76$ \\
\hline \multirow{3}{*}{ Vacuum } & $\mathrm{C}$ & $25.57 \pm 2.59^{\mathrm{ABb}}$ & $25.18 \pm 3.51^{\mathrm{Bab}}$ & $26.21 \pm 1.42^{\mathrm{AB}}$ \\
& $\mathrm{T} 1$ & $28.45 \pm 2.29^{\mathrm{ab}}$ & $22.10 \pm 4.19^{\mathrm{b}}$ & $24.58 \pm 4.61$ \\
& $\mathrm{~T} 2$ & $28.05 \pm 4.30^{\mathrm{ab}}$ & $28.93 \pm 2.26^{\mathrm{a}}$ & $29.47 \pm 3.59$ \\
& $\mathrm{~T} 3$ & $32.05 \pm 1.12^{\mathrm{a}}$ & $24.74 \pm 3.05^{\mathrm{Bab}}$ & $25.15 \pm 2.78^{\mathrm{B}}$ \\
\hline
\end{tabular}

${ }^{11} \mathrm{C}$ was basal diet and $\mathrm{T} 1, \mathrm{~T} 2$, and $\mathrm{T} 3$ was basal diet $+200,400$, and $800 \mathrm{ppm}$ of synthetic lycopene, respectively.

a,b Mean \pm S.D with different superscripts within a column with same packaging differ significantly $(\mathrm{p}<0.05)$.

A,B Mean \pm S.D with different superscripts within a row differ significantly $(\mathrm{p}<0.05)$.

Table 10. Changes of VBN of porks fed lycopene with different packaging during storage at $4^{\circ} \mathrm{C}(\mathrm{n}=3)$

\begin{tabular}{ccccc}
\hline \multirow{2}{*}{ Packaging } & Treatments $^{1)}$ & \multicolumn{3}{c}{ Storage period (days) } \\
\cline { 3 - 5 } & $\mathrm{C}$ & 0 & 5 & 9 \\
\hline \hline \multirow{3}{*}{ Aerobic } & $\mathrm{T} 1$ & $10.91 \pm 1.24^{\mathrm{b}}$ & $9.75 \pm 0.33^{\mathrm{C}}$ & $10.64 \pm 0.61^{\mathrm{b}}$ \\
& $\mathrm{T} 2$ & $15.21 \pm 0.93^{\mathrm{a}}$ & $11.67 \pm 2.37^{\mathrm{Ab}}$ & $11.11 \pm 1.51^{\mathrm{Ab}}$ \\
& $\mathrm{T} 3$ & $14.79 \pm 0.48^{\mathrm{a}}$ & $15.45 \pm 0.93^{\mathrm{a}}$ \\
& $\mathrm{C}$ & $14.47 \pm 1.73^{\mathrm{a}}$ & $14.37 \pm 1.12^{\mathrm{a}}$ & $16.01 \pm 0.82^{\mathrm{a}}$ \\
\hline \multirow{3}{*}{ Vacuum } & $\mathrm{T} 1$ & $10.99 \pm 2.88^{\mathrm{Abc}}$ & $9.43 \pm 0.84^{\mathrm{ABc}}$ & $10.29 \pm 1.25^{\mathrm{Ab}}$ \\
& $\mathrm{T} 2$ & $10.31 \pm 1.33^{\mathrm{ABc}}$ & $11.67 \pm 2.37^{\mathrm{Abc}}$ & $11.11 \pm 1.51^{\mathrm{Ab}}$ \\
& $\mathrm{T} 3$ & $12.65 \pm 0.99^{\mathrm{ab}}$ & $14.19 \pm 2.60^{\mathrm{a}}$ & $14.61 \pm 1.26^{\mathrm{a}}$ \\
& $14.19 \pm 1.51^{\mathrm{ABa}}$ & $12.93 \pm 1.53^{\mathrm{Bab}}$ & $15.31 \pm 1.16^{\mathrm{Aa}}$ \\
\hline
\end{tabular}

${ }^{1)} \mathrm{C}$ was basal diet and $\mathrm{T} 1, \mathrm{~T} 2$, and $\mathrm{T} 3$ was basal diet $+200,400$, and $800 \mathrm{ppm}$ of synthetic lycopene, respectively.

a,b,c Mean \pm S.D with different superscripts within a column with same packaging differ significantly $(\mathrm{p}<0.05)$.

A,B Mean \pm S.D with different superscripts within a row differ significantly $(\mathrm{p}<0.05)$.

처리구간에 통계적인 유의차가 나타나지 않았 다고 보고하고 있다(주, 2005).

본 연구는 라이코펜이 천연의 적색화합물이 며 강력한 항산화제(DiMascio 등, 1989)라는 특 징을 감안해 볼 때 어느 정도 육질의 개선효과 를 기대하였다. 본 실험결과 라이코펜 첨가구 의 보수력이 무첨가구보다 낮았으며, 가열감량
의 경우는 이와 반대로 라이코펜 첨가구가 대 조구보다 더 높은 수치를 나타내었다. 라이코 펜 급여에 따른 돼지고기 육질에 미치는 영향 에 대한 선행연구는 보고 된 바가 거의 없으므 로 좀 더 이와 관련한 많은 연구가 필요할 것 으로 사료된다. 


\section{IV. 요 약}

본 연구는 라이코펜 급여에 따른 재래돼지고 기 등심육의 저장 중 품질특성의 차이를 확인 하기 위하여 실험을 수행하였다. 제주 재래돼 지 농장에서 처리구별로 200 (T1), 400 (T2) 및 $800 \mathrm{ppm}$ (T3)의 라이코펜 급여구를 배치하여 실험을 실시하였다. $\mathrm{pH}$ 의 경우 라이코펜 첨가 의 차이를 확인할 수 없었고, 저장기간 중 총 균수의 경우(Table 3) 저장 0 일차의 대조구(무 첨가구) 보다 라이코펜 첨가구에서 미생물수가 더 낮은 값을 나타내었다 $(\mathrm{p}<0.05)$. 저장기간 중 젖산균수와 대장균군수의 경우 저장 0 일차의 첨가구 $(400,800 \mathrm{ppm})$ 가 무첨가구나 첨가구(200 $\mathrm{ppm}$ ) 보다 유의적으로 더 낮은 값을 나타내었 고. 저장기간에 따라서 함기포장, 진공포장 모 두 대장균군수가 유의적으로 증가하였다 ( $\mathrm{p}<$ 0.05). 또한, 라이코펜 첨가구의 보수력이 무첨 가구 보다 낮았으며, 가열감량의 경우는 이와 반대로 라이코펜 첨가구가 대조구 보다 더 높 은 수치를 나타내었다 $(\mathrm{p}<0.05)$. 이상의 결과를 종합하면 라이코펜 급여 재래돼지고기는 일반 재래돼지고기의 품질과는 다른 미생물수의 차 이를 보였으며 VBN, 보수력 및 가열감량에서 다른 품질 특성을 나타내었으며, 최근 소비자 의 건강지향성 등을 고려할 때 재래 돈육을 생 산하기 위한 기초 자료를 제시할 수 있을 것으 로 사료된다.

\section{$\mathrm{V}$. 인 용 문 헌}

1. Agarwal, S. and Rao, A. V. 1998. Tomato lycopene and low-density lipoprotein oxidation: a human dietary intervention study. Lipids, 33:981984.

2. AOAC. 2000. Official Methods of Analysis. 17th ed, Association of Official Analytical Chemists, Washington, DC, chapter 39. pp. 1-8.

3. Cho, S. H., Park, B. Y., Kim, J. H., Kim, M. J., Seong, P. N., Kim, Y. J., Kim, D. H. and Ahn, C. N. 2007. Carcass yields and meat quality by live weight of Korean native black pigs. J. Anim.
Sci. \& Technol. (Kor.) 49(4):523-530.

4. Choi, Y. S. 2004. Studies on the pork quality of Korean native black pigs and its improvement through dietary manipulation. Ph. D. Thesis. Kangwon National Univ., Chuncheon, Korea. pp. 1-169.

5. DiMascio, P., Kaiser, S. and Sies, S. 1989. Lycopene as the most effective biological carotenoid singlet oxigen quencher. Arch. Biochem. Biophys. 274:532-538.

6. Franceschi, S., Bidoli, E., LaVeccia, C., Talamini, R., D’Avanzo, B. and Negri, E. 1994. Tomatos and risk of digestive tract cancers. Int. J. Cancer. 59:181-184.

7. Giovannucci, E., Ascherio, A., Rimm, E. B., Stampfer, M. J., Colditz, G. A. and Willett, W. C. 1995. Intake of carotenoids and retinol in relation to risk of prostate cancer. J. Natl. Cancer Inst. 87:1767-1776.

8. Jin, S. K., Kim, C. W., Song, Y. M., Jang, W. H., Kim, Y. B., Yeo, J. S., Kim, J. W. and Kang, K. H. 2001. Physicochemical characteristics of longissimus muscle between the Korean native pig and Landrace. Kor. J. Food Sci., 21:143.

9. Jin, S. K., Kim, I. S., Song, Y. M. and Hah, K. H. 2003. Effects of dietary oils and tocopherol supplementation on fatty acid, amino acid, TBARS, VBN and sensory characteristics of pork meat. J. Anim. Sci. \& Technol. (Kor.) 45(2):297308.

10. Kwon, O. S., Park, J. C. and Huh, T. Y. 2001. Korean native black pigs. Standard Guideline for farmer, RDA.

11. Kucuk, O. 2002. Chemoprevention of prostate cancer. Cancer Rev. 21:111-124.

12. Laakkonen, E., Wellington, G. H. and Skerbon, J. W. 1970. Low temperature long time heating of bovine. I. Changes in tenderness, water binding capacity, $\mathrm{pH}$ and amount of water-soluble component. J. Food Sci., 35:175-182.

13. Mascio, P., Kaiser, S. and Sies, H. 1989. Lycopene as the most efficient biological carotenoid 
Kim et al. ; Effects of Lycopene Supplementation and Packaging on Quality Traits in Korean Native Pork

singlet oxygen quencher. Arch. Biochem. Biophys. 274:532-538.

14. Pastori, M., Pfander, H., Boscoboinik, D. and Azzi, A. 1998. Lycopene in association with alphatocopherol inhibits at physiological concentrations proliferation of prostate carcinoma cells. Biochem. Biophys. Res. Comm. 250:582-585.

15. Rao, A. V. and Agarwal, S. 1999. Role of lycopene as antioxidant carotenoid in the prevention of chronic diseases: a review. Nutr. Res. 19:305-323.

16. Ryoichi, S., Degychi, T. and Nagata, Y. 1993. Effectiveness of the filter paper press method for determinating the water holding capacity of meat. Fleischwirtsch, 73:1399.

17. SAS. 2003. SAS/STAT Software for PC. SAS
Institute Inc., Cary, NC, USA.

18. Seo, S. H. and Park, J. Y. 1998. Status of hypertensive patients' drug-taking in health center and its related factors. J. Kor. Soc. Health Education. 15(2):23-43.

19. Sharoni, Y., Giron, E., Rise, M. and Levy, J. 1997. Effects of lycopene-enriched tomato oleorsin on 7, 12-dimethyl-benz (a) antracene-induced rat mammary tumors, Cancer Detect. Prev. 21:118123.

20. 高坂和久. 1975. 肉製品の鮮度保持と測定. 食品 工業. 18:105-111.

21. 주원돈. 2005. 라이코펜의 사료내 첨가가 닭과 돼지의 지질대사 및 항산화에 미치는 영향. 건국 대학교 박사학위 논문

(접수일자 : 2008. 1. 2. / 채택일자 : 2008. 3. 26.) 